University of Nebraska - Lincoln

DigitalCommons@University of Nebraska - Lincoln

University of Nebraska Press -- Sample Books

and Chapters

University of Nebraska Press

2011

Deterrence through Strength

Rebecca Berens Matzke

Follow this and additional works at: https://digitalcommons.unl.edu/unpresssamples

Part of the Arts and Humanities Commons

Matzke, Rebecca Berens, "Deterrence through Strength" (2011). University of Nebraska Press -- Sample Books and Chapters. 106.

https://digitalcommons.unl.edu/unpresssamples/106

This Article is brought to you for free and open access by the University of Nebraska Press at DigitalCommons@University of Nebraska - Lincoln. It has been accepted for inclusion in University of Nebraska Press -- Sample Books and Chapters by an authorized administrator of DigitalCommons@University of Nebraska - Lincoln. 


\section{Deterrence through Strength}


Studies in War, Society, and the Military

GENERAL EDITORS

Peter Maslowski

University of Nebraska-Lincoln

David Graff

Kansas State University

Reina Pennington

Norwich University

EDITORIAL BOARD

D'Ann Campbell

Director of Government and

Foundation Relations,

U.S. Coast Guard Foundation

Mark A. Clodfelter

National War College

Brooks D. Simpson

Arizona State University

Roger J. Spiller

George C. Marshall Professor

of Military History

U.S. Army Command and

General Staff College (retired)

Timothy H. E. Travers

University of Calgary

Arthur Waldron

Lauder Professor of

International Relations

University of Pennsylvania 

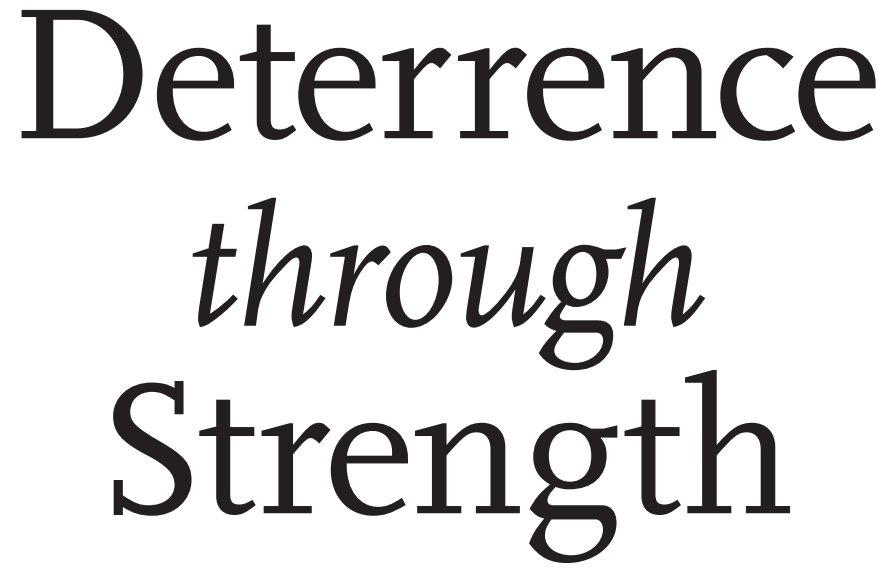

British Naval Power and Foreign Policy under Pax Britannica

REBECCA B ERENS M ATZKE

University of Nebraska Press | Lincoln and London 
(C) 20II by the Board of Regents of the University of Nebraska

All rights reserved

Manufactured in the

United States of America

(2)

Library of Congress Cataloging-

in-Publication Data

Matzke, Rebecca Berens.

Deterrence through strength:

British naval power and foreign policy

under pax britannica /

Rebecca Berens Matzke.

p. cm.-(Studies in war, society,

and the military)

Includes bibliographical references and index.

ISBN 978-0-8032-35I4-4 (cloth: alk. paper)

I. Great Britain-Foreign relations-I837-I90I.

2. Great Britain-History, Naval—Igth century.

3. Sea power-Great Britain-History-Igth

century. 4. Deterrence (Strategy). 5. Great

Britain-Foreign relations-United States.

6. United States-Foreign relations-Great

Britain. 7. Great Britain-Foreign relations-

China. 8. China-Foreign relations-Great

Britain. 9. Great Britain-Foreign relations-

Mediterranean Region. Io. Mediterranean

Region-Foreign relations-Great Britain.

I. Title.

DA55O.M37 2OII

327.41009'034-dc22 2010051604

Set in Scala by Bob Reitz. 


\title{
Contents
}

\author{
List of Maps vi \\ Preface vii
}

Acknowledgments ix

I. British Power in the Early Victorian Period I

2. Politics, Policymaking, Principles, and Strategy II

3. The Instruments of Power 37

4. Britain Gets Its Way in North America 65

5. China: Adjusting the Signal I05

6. The Mediterranean and the Problem of France 155

7. Restoring Britannica to Pax Britannica 2I7

Notes 227

Bibliography 289

Index 30I 
Maps

I. Boundaries in North America: Britain and the Expanding United States 68

2. Coastal China, I840 Io6

3. The Mediterranean and Egypt, I840 158 


\section{Preface}

In the past several decades historians have expressed doubt about the validity of a Pax Britannica. The point of entry for this research was an impression that such doubts seemed, first, to be part of a general trend of projecting the decline of Britain's power and influence onto an earlier era, and second, to have sprung from a mistaken conception of British objectives. The trailblazing work of Andrew Lambert on the capabilities of the traditional British sailing fleet and new British naval technologies in the nineteenth century raised further suspicion that the British power employed to influence other nations was being overlooked.

The period at the beginning of Queen Victoria's reign, I 838 to I 846 , provides ample opportunities for testing the idea that Britain could and did use its navy effectively to accomplish diplomatic and commercial goals. It contained instances of Britain threatening naval force (against the United States and France) and actually using it (against China and Egypt). This period also ushered in an era of swift technological change, as the Royal Navy and its competitors adopted steam-powered warships. It was long enough after the Napoleonic Wars to be free of the idiosyncrasies of immediate 
postwar naval policy. And, finally, existing historical studies scarcely address the relationship of Britain's naval capabilities to its foreign policy in this period.

Because British foreign policymaking was not bureaucratized in the mid-nineteenth century, much of the substance of decision making could not be found in official dispatches and records. Thus, the majority of my research focused on the private correspondence, notes, and journals of statesmen, drawing out the goals and strategies of British policy and the ways in which it was often implemented by naval power.

This volume aims to demonstrate through three case studies—of North America, China, and the Mediterranean—that Britain influenced other nations with its navy, but it always did so with the ultimate goals of preserving peace, stability, and British diplomatic freedom. The apparent contradictions of this defensive policy based on offensive capabilities offer intriguing insights into the ways a dominant world power calculated its interests and decided whether to exercise its naval supremacy.

Several of the quotations in this book include variant spellings, which have been preserved in their original forms. The ruler of Egypt during the Syrian Crisis is thus referred to here as Mehemet Ali, rather than Mohammed Ali, following the spellings and conventions used by early Victorian British officials. Chinese person and place names are transliterated in pinyin style, with the exception of quotations and map labels, which will contain the original transliteration of the sources, and the commonly used Wade-Giles place names Canton, Peking, and Nanking. Translations of French quotations have been provided by Dominique Poncelet except where otherwise noted. 


\section{Acknowledgments}

The help, thoughts, and advice of many people have gone into the writing of this book. It began as a dissertation for Cornell University and has been completed during my time on the faculty at Ripon College.

I gratefully acknowledge the permission of the following to quote from certain collections: the Trustees of the Broadlands Archives and the Controller of Her Majesty's Stationery Office (Hмso) for the Palmerston Papers, the Controller of нмso for the Wellington Papers housed at Hartley Library in Southampton, the Trustees of the National Maritime Museum for the Minto (Elliot) Papers in their care, and the Trustees of the National Library of Scotland for the Minto Papers housed there.

An earlier version of chapter four of this book was previously published as "Britain Gets Its Way: Power and Peace in Anglo-American Relations I838-I846" in the SAGe Publications journal War In History 8, no. I (200I).

I am grateful for the financial support of the Cornell University Graduate School, the Department of History, and the Mario Einaudi Center for International Studies, which enabled me to conduct extensive research in the United Kingdom. I 
also thank the Institute for European Studies for a Michele Sicca Pre-Dissertation Research Grant and the Mellon Foundation for dissertation fellowships.

Many professional colleagues assisted me with thoughtprovoking comments and suggestions at various points in my research and writing. Andrew Lambert of King's College London and John Beeler of the University of Alabama offered particular help on the nineteenth-century Royal Navy. Sherman Cochran, Isabel Hull, and Walter LaFeber of Cornell University gave valuable suggestions for converting the dissertation to a book. My colleagues in the history department at Ripon College have cheered me on in the rewriting phase, and Dominique Poncelet of the French department was kind enough to provide English translations of many of the French quotations in the book. Very special thanks are also due to two mentors I am glad to count as friends: Peter Maslowski of the University of Nebraska and Daniel Baugh of Cornell. Both have encouraged and guided me in this project, and I am beyond lucky to have been able to work with them these many years.

Finally, I thank my family for their support. My parents fielded questions and shuttled library books, and my sister Rachel proofread the final draft of the manuscript. Kit and Will have grown up with this project, providing wonderful distractions and always putting my academic work into perspective. And no words can express my gratitude to Bill. 
British Power in the Early Victorian Period

n I893 Joseph Chamberlain popularized the term Pax Britannica to describe an era that had begun with the end intended the phrase to explain the pacifying effects of Britain's rule in India, it eventually came to be understood as the broader phenomenon whereby Britain's overwhelming strength enforced global peace from Napoleon's defeat until the late nineteenth century. Britain's commercial, industrial, financial, and imperial might, all protected by the superior Royal Navy, were so imposing that they deterred war, either by compelling other nations and peoples to defer to Britain's will, or at least by inviting them to bask in the safety afforded by a navy that upheld the status quo. The absence of large, general European wars gave credence to the concept.

The idea of a Pax Britannica, however, seems to have gone out with the British Empire itself. Since the I96os the general consensus has held that the concept is misleading at best. Whether critics address the notion of Pax Britannica directly or speculate on it in larger discussions of British foreign policy, naval power, or empire, they usually emphasize that Britain had only limited means of exercising power at the 
time, and that British military or naval strength played little role in preserving peace.

Two questions arise about the concept of a Pax Britannica. The first concerns the Pax part of the term: was the period from I8I5 to I880 really as peaceful as the phrase implies? As many historians have pointed out, the answer is a decided no. True, there was no great European war in this period. The Crimean War (1853-56) was the only conflict between more than two great powers, and it was fairly limited in terms of participants, length, and geographic scope. Still, numerous other military occupations, naval demonstrations, bombardments, blockades, and small wars went on throughout the world during the so-called Pax. ${ }^{2}$ Britain took part in many such operations, and although they have been labeled wars of a "remote colonial kind," they were not always remote or colonial, as the Syrian Crisis in the Mediterranean and near war with the United States make clear. ${ }^{3}$ Although one should keep in mind that many nations, especially Britain, used or threatened to use armed force throughout much of the century, most historians still consider this period something special. ${ }^{4}$ It stands in marked contrast to the eighteenth century, when lengthy coalition wars were commonplace and their recurrence was a continual threat in times of peace. Perhaps the Pax of the nineteenth century was not entirely peaceful, but Europe was relatively free of general wars.

The second question regarding Pax Britannica pertains to the Britannica portion of the term: was this peace a British peace? That is, did Great Britain possess power that was dominant and penetrating enough to impose its will in serious diplomatic disputes? And was it therefore able to preserve 
peace, protect its interests, and deter potential competitors? Most scholars in the past several decades have also answered no to these questions when applied to great power relations. They often acknowledge the relative strength of the Royal Navy and note Britain's successful "gunboat diplomacy" against smaller states. ${ }^{5}$ They might recognize Britain's commercial and industrial superiority and its empire, all of which provided it with resources for a war, especially at sea. ${ }^{6}$ But most doubt that Britain's use of naval and military force - or its threat to use force - played any significant role in European affairs, even if it may have helped facilitate peace in the wider world. They instead emphasize that a naval power like Britain could not influence continental powers because it lacked a large army and ultimately needed the help of a continental ally that had one. Continental states were supposedly invulnerable to blockades or cannon fire, much less to mere intimidation by a fleet, because they are assumed to have had expansive armies, internal lines of communication, and self-sufficient economies. So Britain could only interfere from the sidelines, and the peace of Europe instead depended on a European concert. ${ }^{7}$ Diplomatic histories of the period point to balanceof-power politics in a European system, not naval power, as being responsible for peace. ${ }^{8}$

Demonstrating Britain's inability to exercise power usually involves listing diplomatic incidents in which Britain did not intervene with force. Historians have interpreted these occasions as evidence that Britain was unable to make its power felt, and as proof, therefore, that British naval dominance (at least in the developed world) was an illusion. The examples given include Britain's supposed failures to stop France's 
incursion into Spain in I825, to intervene to resolve the MaineNew Brunswick boundary question with the United States in the early I840s, to use the Royal Navy to win the Crimean War, or to prevent Prussia's occupation of Schleswig-Holstein in I864. In effect, each situation in which a historian has judged that Britain had reason to act but did not becomes an exhibit in the case against the capacity of British naval power to exert any influence at all. ${ }^{9}$ However, many works do not address disputes that involved the threat of force or limited action short of war, nor do they go beyond lists to analyze whether Britain did in fact require a continental ally with a great army to influence European politics or keep the peace.

Having raised doubts about its naval and military capabilities, historians often credit Britain's dominant position from I8I5 to I880 to "circumstances" resulting from the Napoleonic Wars. The lengthy coalition wars stimulated Britain's industry and increased its national wealth, while they shut the other great powers (both opponents and allies) out of overseas markets, detached their imperial territories, sucked their treasuries dry, and damaged their infrastructures. ${ }^{10}$ In this scenario Britain seems to have experienced a cycle in which its economic and financial dominance - boosted by the great wars — sustained its relative naval supremacy, which in turn protected its economic and financial health. Britain's superior economic strength translated (seemingly automatically) into a big, strong navy and the ability to outlast enemies in a war, both of which made Britain more powerful than its European competitors. Britain's wartime naval successes might also have been useful to bluff later on. Relying on its rivals' memories of Adm. Viscount Horatio Nelson's exploits, 
the Royal Navy could exercise more influence than its actual strength should have allowed. ${ }^{11}$

All of these arguments note Britain's post-I8I5 assets, but they emphasize "negative" reasons for Britain's relative power and the period of general peace. Circumstances were benign for Britain, these arguments posit, and great power rivals simply did not bother to compete. ${ }^{12}$ The implication that other European states could have altered their economic and industrial situations at any time, had they decided to do so, adds an element of political will to the power equation. Exhausted after I8I5, European rulers were conservative, mindful of their countries' frailties, and intent on solving their domestic economic and social problems. ${ }^{13}$ Mutual suspicions (and lingering distrust of France) discouraged them from cooperating to contest Britain's naval and imperial lead and offered Britain opportunities to play the powers against each other diplomatically. ${ }^{14}$ In this view the great powers' choice not to challenge Britain was grounded in their dedication to the status quo in Europe. Because Britain was the only economic and naval powerhouse left standing after I8I5, this commitment was the true cause of both peace and British dominance.

Happily, this argument continues, British policies offered European states positive reasons to either become Britain's allies or simply tolerate its relative supremacy. Britain's general commitment to peace and its choice to use naval mastery to promote free trade helped everyone. Other powers might not like Britain's command of the sea, but they put aside their objections with a view toward material gain. ${ }^{15}$

If Britain's dominance was merely circumstantial, and if it could not decisively affect continental nations with its navy, 
then perhaps British power played only a marginal role in preserving peace, and the real credit should go to the Concert of Europe. Sometimes the concert seems built on a new spirit of cooperation after I8I5, in which states generally agreed on objectives and international rules. The rules and the powers' mutual interest in preserving a concert kept the peace. Others argue that the system worked not only because of consensus on the need for a balance of power, but also because the powers could shift their alliances within the system for different purposes without war. ${ }^{16}$

But could the European system really have operated with no consideration for the relative strength of its member states? Britain played a key role in upholding the concert because of its relative strength. The powers' willingness to act to enforce peace and the status quo was vital to preserving equilibrium, and Britain could take that action. It has even been suggested that the peaceful European system disintegrated largely because Britain decided after the Crimean War to abandon its tradition of active involvement in Europe. ${ }^{17}$ Since it is unlikely that Britain's participation in the concert was necessary simply because of the nation's moral weight, its importance was likely based on real power: naval strength backed by economic and financial strength. Britain was disproportionately responsible for maintaining the system because it was the one great power that possessed the ability to influence Europe - it could "mobiliz[e] resources to alter the behavior of others"18 — but also lacked the continental ambitions that would have made it dangerous and destabilizing.

Much work of the past fifty years has been an inevitable revision of overly whiggish assumptions about British imperial 
power, but its emphasis on circumstances and limited British naval power went too far. A more recent rethinking of the Royal Navy's role in the Crimean War opens the door to reconsidering Britain's naval capabilities and the ways in which power upheld both British interests and a Pax Britannica.

The widely held belief outlined above often centered on the example of the Royal Navy's apparent ineffectiveness in the Crimean War. The common view supposed that only armies - and those mostly French - were able to beat Russia into submission. Fresh interpretations, however, show that the Royal Navy played the decisive part in winning the war. It carried and supplied the allied army in the Crimea for year and a half, devastated Russia's economy with its blockade, and smashed several Russian fortresses on its way to threatening Cronstadt, the Baltic fortress guarding the capital, St. Petersburg. This threat, made possible by steam warships, forced the tsar's government to accept terms that crippled Russia's naval power and its sway in eastern Europe for decades to come. ${ }^{19}$ Evidence that Britain's naval capabilities were so effective against the archetypal land power casts doubt on notions of limited British power. Moreover, France and the United States were vulnerable to the Royal Navy as well, and they all built coastal defenses to protect themselves against the sea power they so feared. ${ }^{20}$

British power and British goals, therefore, deserve to be reassessed. The assumption that Britain's naval power was inadequate and ineffective because Britain did not constantly exercise it in blockades, bombardments, or actual wars against continental states misses the point. The Royal Navy's main role in the nineteenth century was to be a deterrent force, 
and it played that role skillfully. With its intimidating fleet afloat - especially after steam technology enhanced its inshore operations - its great reserves and shipbuilding capacity, and its secure financial, economic, and political supports, Britain's navy was visible and credible. British naval power posed a genuine threat, but British governments exercised discretion in using it. On some occasions they chose not to act, but inaction did not necessarily mean that the British battle fleet was too weak to assert British influence. When they chose to, British leaders used the navy to signal their intentions, warning other nations away in conflicts that endangered British interests. British statesmen were prepared to use its force to guard Britain's interests - and maintenance of peace was, generally speaking, one of those interests - but they rarely needed to do so. ${ }^{21}$

If one takes deterrence as Britain's main foreign policy strategy in this era, a scarcity of naval actions would be a measure of its success. British policy in North America, China, and the Mediterranean from I838 to I846 reveals the ways British leaders considered British interests and applied naval and military force rationally and discreetly. With respect to power, British capabilities were greater than are usually assumed, and British statesmen of the time knew how to employ these capabilities while recognizing their limits. As for British interests, historians have sometimes neglected Britain's real objectives and important factors involved in decision making. Situations in which Britain did not use force should be reconsidered, and its goals and methods should be explored rather than passed over in a presumption that British naval power was insufficient. 
Examining Britain's handling of force - both its threat and its use - can aid in understanding the nation's power capabilities and its primary goals. This will provide a clearer picture of British power and policy during the period from I838 to I846, a period in which British governments confronted several crises that demanded decisions on the use of naval force. It will also suggest that British power created at least some of the circumstances that shaped the attitudes of European powers. What follows aims not only to put the Britannica back into Pax Britannica, but also to show how Britain's influence, whether in Europe or the wider world, derived not just from industrial, financial, and commercial dominance, but from naval power as well. 